\title{
PENGGUNAAN MEDIA PEMBELAJARAN BERBASIS TIK UNTUK MENINGKATKAN HASIL BELAJAR IPS KELAS VIII J SMP NEGERI 5 SINGARAJA
}

\author{
Hendri Harliawan \\ Jurusan Pendidikan Ekonomi, Fakultas Ekonomi \& Bisnis \\ Universitas Pendidikan Ganesha \\ Singaraja, Indonesia \\ e-mail: enjisah@yahoo.com, lulup tripalupi@yahoo.com, \\ luh.indrayani@yahoo.co.id
}

\begin{abstract}
ABSTRAK
Penelitian ini bertujuan untuk mengetahui penggunaan media pembelajaran interaktif berbasis Teknologi, Informasi, dan Komunikasi (TIK) dalam meningkatkan hasil belajar IPS Terpadu pada siswa kelas VIII J di SMP Negeri 5 Singaraja tahun pelajaran 2013/2014, dan mengetahui respons siswa terhadap penggunaan media pembelajaran interaktif berbasis TIK pada mata pelajaran IPS Terpadu di kelas VIII J di SMP Negeri 5 Singaraja tahun pelajaran 2013/2014. Penelitian ini merupakan Penelitian Tindakan Kelas (PTK). Penelitian ini dilakukan dalam dua siklus pembelajaran dengan tahapan-tahapan dalam setiap siklus meliputi perencanaan, tindakan, observasi dan evaluasi, serta refleksi. Data hasil belajar siswa dikumpulkan melalui tes hasil belajar pada akhir setiap siklus. Data respon siswa dikumpulkan melalui penyebaran angket/kuesioner. Data yang telah terkumpul selanjutnya dianalisis secara deskriptif. Hasil penelitian ini menunjukkan, (1) penggunaan media pembelajaran interaktif berbasis TIK dapat meningkatkan hasil belajar siswa. Hal ini ditunjukkan dengan jumlah siswa yang telah tuntas pada siklus I sebesar $65,52 \%$, sedangkan pada siklus II jumlah siswa yang telah tuntas adalah sebesar $93,10 \%$, dan (2) respons siswa terhadap penggunaan media pembelajaran interaktif berbasis TIK diperoleh skor ratarata sebesar 41,72 dengan kategori positif.
\end{abstract}

Kata Kunci: Hasil belajar, Respons siswa, TIK

\begin{abstract}
This study aims to determine the use of interactive learning media based on Teknologi, Informasi, dan Komunikasi (ICT) in improving learning outcomes in the Integrated IPS VIII J grade students at SMP Negeri 5 Singaraja academic year 2013/2014, and determine students' responses the use of ICT based interactive learning media on subjects in class VIII Integrated IPS J in SMP Negeri 5 Singaraja academic year 2013/2014. This research is Classroom Action Research (CAR). The research was conducted in two cycles of learning with the stages in each cycle includes planning, action, observation and evaluation, and reflection. Student learning outcomes data collected through achievement test at the end of each cycle. Student response data collected through questionnaires/questionnaires. Collected data was then analyzed descriptively. The results showed, (1) the use of ICT based interactive learning media can improve student learning outcomes. This is indicated by the number of students who have completed the first cycle of $65.52 \%$, while in the second cycle the number of students who have completed amounted to $93.10 \%$, and (2) the response of students to the use of ICT based interactive learning media obtained average scores average of 41.72 with the positive category.
\end{abstract}

Key Words: ICT, Learning outcomes, Student response

\section{PENDAHULUAN}

Penerapan standar proses pendidikan merupakan kebijakan yang sangat penting dan strategis untuk pemerataan dan peningkatan kualitas pendidikan. Secara umum, peningkatan kualitas pendidikan telah direncanakan dan dilaksanakan saat ini, terbukti dari adanya penyempurnaan dan pelaksanaan kurikulum 2013. Melalui standar proses guru dapat menentukan bagaimana seharusnya proses pembelajaran berlangsung. Kurikulum 
dan perangkat belajar yang lain seperti silabus dan Rencana Pelaksanaan Pembelajaran (RPP) telah mengacu pada standar proses yang telah ditetapkan dan merupakan suatu hal yang harus diperhatikan oleh seorang guru dalam proses pembelajaran di dalam kelas.

Observasi awal di Sekolah Menengah Pertama (SMP) Negeri 5 Singaraja kelas VIII J pada mata pelajaran IImu Pengetahuan Sosial (IPS) Terpadu Tahun Pelajaran 2012/2013 menunjukkan hasil belajar siswa masih tergolong rendah. Selain itu jumlah siswa yang berhasil mencapai dan melampaui Kriteria Ketuntasan Minimum (KKM) kurang dari $50 \%$. Sedangkan untuk KKM pada mata pelajaran IPS Terpadu Tahun Pelajaran 2012/2013 adalah 70. Jumlah siswa yang berhasil mencapai dan melampaui KKM yang kurang dari 50\% tersebut menyebabkan guru harus melakukan pembelajaran remedial. Kemudian, pada Tahun Pelajaran 2013/2014 KKM mata pelajaran IPS Terpadu telah ditingkatkan menjadi 72 , hal ini berarti bahwa kemungkinan persentase siswa yang tidak dapat mencapai dan melampaui KKM semakin besar.

Beberapa penyebab rendahnya persentase siswa yang mencapai dan melampaui KKM pada mata peajaran IPS Terpadu di kelas VIII J SMP Negeri 5 Singaraja adalah (1) pembelajaran yang dilakukan oleh guru pada mata pelajaran IPS terpadu hanyalah sebatas ceramah, dan (2) kurangnya penggunaan media pembelajaran yang semestinya mampu memfasilitasi perolehan pemahaman bagi siswa pada mata pelajaran IPS Terpadu. Kondisi demikian apabila terus dibiarkan akan berdampak buruk terhadap kualitas pembelajaran mata pelajaran IPS Terpadu di kelas VIII J SMP Negeri 5 Singaraja yang akan berimplikasi pula pada hasil belajar IPS yang dicapai oleh siswa.

Oleh karena itu untuk memperbaiki hasil belajar siswa pada mata pelajaran IPS Terpadu kelas VIII J SMP Negeri 5 Singaraja adalah dengan penggunaan media pembelajaran Interaktif berbasis Teknologi, Informasi, dan Komunikasi (TIK) karena media pembelajaran Interaktif berbasis TIK merupakan media yang dapat digunakan untuk menyalurkan pesan dari pengirim ke penerima sehingga dapat merangsang pikiran, perasaan, dan minat serta perhatian siswa, sehingga proses pembelajaran di dalam kelas terjadi.

"Belajar pada prinsipnya adalah suatu proses usaha yang dilakukan seseorang untuk memperoleh suatu perubahan tingkah laku yang baru secara keseluruhan, sebagai hasil pengalamannya sendiri dalam interaksi dengan lingkungannya" (Slameto, 2003: 2).

\section{National Education Association}

(NEA) (dalam Usman dan Asnawir, 2002: 11) mendefinisikan "media pembelajaran sebagai benda yang dapat dimanipulasi, dilihat, didengar, dibaca atau dibicarakan beserta instrumen yang dipergunakan dengan baik dalam kegiatan belajar mengajar, serta dapat mempengaruhi efektifitas program instruksional".

Sedangkan Arsyad (2009: 4) mengatakan bahwa "media adalah sumber belajar atau wahana fisik yang mengandung materi intruksional di lingkungan siswa yang dapat merangsang siswa untuk belajar, dan istilah media bahkan sering dikaitkan dengan kata 'teknologi'". Jadi dapat disimpulkan bahwa media adalah alat, metode, dan teknik yang digunakan dalam rangka lebih mengefektifkan komunikasi dan interaksi antara guru dan siswa dalam proses pendidikan dan pengajaran di sekolah.

Pada dasarnya siswa belajar melalui benda atau objek konkrit. Untuk memahami konsep abstrak siswa memerlukan benda-benda konkrit (riil) sebagai perantara atau visualisasinya. Konsep abstrak itu dicapai melalui tingkatan-tingkatan belajar yang berbeda-beda, bahkan orang dewasa yang pada umumnya sudah dapat memahami konsep abstrak, pada 
keadaan tertentu sering memerlukan visualisasi.

Selanjutnya konsep abstrak yang diungkapkan oleh Dale (dalam Arsyad, 2009: 10), tentang kerucut pengalaman belajar dan hasil belajar dimana, $75 \%$ diperoleh melalui indera pandang (mata), $13 \%$ melalui indera dengar, dan melalui indera lain sekitar $12 \%$.

Menurut Seels \& Glasgow (dalam Arsyad, 2002: 33) "media interaktif merupakan kelompok pilihan media teknologi mutakhir". Media teknologi mutakhir sendiri dibedakan menjadi (1) media berbasis telekomunikasi, misal teleconference, kuliah jarak jauh, dan (2) media berbasis mikroprosesor, misal computer-assistted instruction, permainan komputer, sistem tutor intelejen, interaktif, hypermedia, dan compact (video) disc.

Media pembelajaran interaktif adalah suatu sistem penyampaian pengajaran yang menyajikan materi video rekaman dengan pengendalian komputer kepada siswa yang tidak hanya mendengar dan melihat video dan suara, tetapi juga memberikan respon yang aktif, dan respon itu yang menentukan kecepatan dan sekuensi penyajian (Seels \& Glasgow dalam Arsyad, 2002: 36).

$\begin{array}{cr}\text { Perkembangan } & \text { Teknologi, } \\ \text { Informasi } & \text { dan } \\ \text { Komunikasi }\end{array}$ memungkinkan pemanfaatan fungsi berbagai media pembelajaran dengan menggunakan satu alat yang disebut multimedia, yang mampu menyampaikan informasi dan materi pembelajaran dalam bentuk teks, gambar, suara, animasi, film, bahkan interaksi. Komputer adalah salah satu alat multimedia, karena komputer mampu menyajikan informasi dan materi pembelajaran dalam semua bentuk, bahkan dengan komputer situasi nyata yang memerlukan waktu lama atau sangat mahal dan mengandung resiko dapat disimulasikan dengan komputer (misalnya proses reaksi kimia, dampak suatu ledakan nuklir, perjalanan tata surya, dll.).
Melalui multimedia, konsep-konsep abstrak dapat disajikan secara lebih nyata dalam proses pembelajaran untuk memudahkan siswa memahaminya.

TIK mencakup semua teknologi yang dapat digunakan untuk menyimpan, mengolah, menampilkan, dan menyampaikan informasi dalam proses komunikasi. Yang termasuk teknologi ini adalah sebagai berikut.

(1) Teknologi komputer, baik perangkat keras (hardware) maupun perangkat lunak (software) pendukungnya. $\mathrm{Di}$ dalamnya termasuk prosesor (pengolah data), media penyimpan data/informasi (hard disk, Compact Disk (CD), Digital Versatile Disc (DVD), flash disk, memori, kartu memori, dll.), alat perekam, alat input (keyboard, mouse, scanner, kamera, dll.), dan alat output (layar monitor, printer, Liquid Crystal Display (LCD), speaker, dil.).

(2) Teknologi multimedia, seperti kamera digital, kamera video, player suara, player video, dan lainlain.

(3) Teknologi telekomunikasi, telepon, telepon seluler, faksimail.

(4) Teknologi jaringan komputer, baik perangkat keras (Local Area Network (LAN), internet, Wireless Fidelity (wifi), dll.), maupun perangkat lunak pendukungnya (aplikasi jaringan) seperti word elektrik browser (web), e-mail, Hyper Text Markup Language (HTML), java, Hypertext Preprocessor (PHP), aplikasi basis data, dan lain-lain.

Di kalangan umum, istilah TIK lebih merujuk pada teknologi komputer. Hal ini tidaklah mengherankan karena komputer pada saat ini selain berfungsi sebagai alat pengolah data juga dapat berfungsi untuk komunikasi melalui jaringan komputer (internet) serta alat multimedia (hiburan). Hampir semua komponen TIK sekarang ini dapat dipakai secara bersama-sama dengan komputer. Jadi, untuk saat ini istilah TIK dan komputer hampir dapat disama artikan jika ditinjau dari fungsinya. 
Menurut Krisnadi (2009) berbagai upaya telah dilakukan oleh dunia pendidikan untuk meningkatkan kualitas pendidikan, khususnya kualitas pembelajaran melalui pemanfaatan media TIK. Selain fungsinya sebagai alat bantu pemecahan masalah manusia, media TIK juga dapat dimanfaatkan untuk mendukung proses pembelajaran yang dipercaya dapat: (1) meningkatkan kualitas pembelajaran, (2) memperluas akses terhadap pendidikan dan pembelajaran, (3) mengurangi biaya pendidikan, (4) menjawab keharusan berpartisipasi dalam TIK, dan (5) mengembangkan keterampilan TIK (ICT skills) yang diperlukan siswa ketika bekerja dan dalam kehidupannya nanti.

Perkembangan penggunaan media TIK dipengaruhi oleh teori belajar konstruktivisme, komputer dimanfaatkan untuk membantu siswa menemukan dan merumuskan pengetahuannya melalui interaksi dan eksplorasi sumber-sumber belajar berbasis TIK. Selain itu, pemanfaatan TIK dalam pembelajaran juga mendukung teori socio-constructivism, yakni siswa memperoleh pengalaman belajar secara bersama-sama dengan siswa lain atau melalui interaksi dengan para pakar dengan media komunikasi berbasis TIK. Perkembangan terkini adalah pemanfaatan TIK secara terpadu di dalam pembelajaran yang memadukan berbagai keterampilan dan fungsi TIK di dalam proses belajar mengajar.

Penggunaan TIK sebagai media pembelajaran dapat berbentuk file slide microsoft office power point, gambar, animasi, video, audio, program CAI (computer aided instruction), program simulasi, dan lain-lain. Penggunaan media berbasis TIK memberikan beberapa keuntungan diantaranya, (1) memvisualisasikan konsep-konsep abstrak, (2) mempermudah memahami materi-materi yang sulit, (3) mensimulasikan proses yang sulit dilakukan secara manual, (4) menampilkan materi pembelajaran dalam berbagai format (multimedia) sehingga menjadi lebih menarik, dan terbaru (up to date) dari berbagai sumber, (5) memungkinkan terjadinya interaksi antara pebelajar dan materi pembelajaran, (6) mengakomodir perbedaan kecepatan dan gaya belajar siswa, (7) mengatasi keterbatasan ruang, waktu, dan tenaga, (8) mendukung perubahan peran guru ke arah yang positif sebagai fasilitator dan mediator, dari posisi semula sebagai satu-satunya sumber pengetahuan, (9) meningkatkan keterampilan individu penggunanya.

Hasil belajar merupakan kemampuan yang dimiliki seseorang sebagai hasil dari proses belajar, ataupun merupakan penguasaan pengetahuan keterampilan yang dikembangkan oleh mata pelajaran, yang biasanya ditunjukkan dengan nilai tes atau nilai yang diberikan guru. Menurut Sudjana (2005: 22) bahwa "hasil belajar merupakan kemampuan yang dimiliki siswa setelah ia menerima pengalaman belajar". Jadi hasil belajar adalah akibat dari suatu aktivitas yang dapat diketahui perubahannya dalam pengetahuan, pemahaman, ketrampilan, dan nilai sikap melalui ujian tes atau ujian.

Bloom (dalam Sudjana, 2005: 22) membagi hasil belajar menjadi tiga ranah, yakni ranah kognitif, ranah afektif dan ranah psikomotoris. Ranah kognitif berkenaan dengan hasil belajar intelektual, ranah afektif berkenaan dengan sikap dan ranah psikomotorik berkenaan dengan ketermpilan dan kemampuan bertindak.

Sedangkan Kingsley (dalam Sudjana, 2004: 45) membagi tiga macam hasil belajar yaitu, (1) keterampilan dan kebiasaan, (2) pengetahuan dan pengertian, dan (3) sikap dan cita-cita, yang masing-masing golongan dapat diisi dengan bahan yang ditetapkan dalam kurikulum sekolah. Berdasarkan beberapa pendapat yang telah diutarakan di atas mengenai pengertian hasil belajar, maka dapat disimpulkan bahwa hasil belajar adalah perubahan yang terjadi pada diri seseorang setelah melalui 
suatu proses belajar mengajar, baik dari segi kognitifnya (pengetahuan), afektifnya (sikap) maupun dari segi psikomotoriknya (keterampilan).

Djamarah (2003) menyatakan bahwa berhasil atau tidaknya seseorang dalam belajar disebabkan oleh faktor yang berasal dari dalam diri individu dan faktor dari luar individu. Clark (dalam Sabri, 2005) mendukung hal tersebut dengan menyatakan bahwa $70 \%$ hasil belajar siswa di sekolah dipengaruhi oleh kemampuan siswa dan 30\% dipengaruhi lingkungan. Sedangkan menurut Slameto (2003) faktor-faktor yang mempengaruhi hasil belajar siswa digolongkan menjadi dua, yaitu faktor intern dan faktor ekstern.

Ilmu Pengetahuan Sosial (IPS) merupakan sub program pendidikan pada tingkat pendidikan dasar dan menengah. Istilah lain yang muncul selain dari nama Pendidikan IPS ini adalah Studi Sosial. Istilah ini diperkenalkan di Indonesia pada Tahun 1971, pada 'Seminar National Civics Education di Tawangmangu-Solo, sebagai terjemahan dari istilah "Social Studies" yang telah digunakan di Amerika untuk mata pelajaran ini dalam kurikulum Sekolahnya". Kendatipun istilah ini tidak dijadikan nama bagi Pendidikan IPS, namun menurut AI Mukhtar, istilah ini terus berkembang sebagai sebutan konseptual dalam pembaharuan pendidikan IPS yang secara operasional lebih berperan sebagai pendekatan dalam pengembangan kurikulum Pendidikan IPS.

\begin{tabular}{lcr}
\multicolumn{3}{c}{ Penelitian ini bertujuan untuk (1) } \\
mengetahui penggunaan media \\
pembelajaran interaktif berbasis
\end{tabular} Teknologi, Informasi, dan Komunikasi (TIK) dalam meningkatkan hasil belajar IPS Terpadu pada siswa kelas VIII J di SMP Negeri 5 Singaraja tahun pelajaran 2013/2014, (2) mengetahui respons siswa terhadap penggunaan media pembelajaran interaktif berbasis TIK pada mata pelajaran IPS Terpadu di kelas VIII J di SMP Negeri 5 Singaraja tahun pelajaran 2013/2014.

\section{METODE}

Dilihat dari aspek metodologis, penelitian ini menggunakan metode Penelitian Tindakan Kelas (PTK) atau Classroom Action Research (CAR), yang pada hakekatnya merupakan penelitian tindakan yang bertujuan meningkatkan dan memperbaiki kualitas proses pembelajaran di kelas VIII J SMP Negeri 5 Singaraja yang bermuara pada hasil belajar IImu Pengetahuan Sosial (IPS) Terpadu.

Subjek dalam penelitian ini adalah siswa kelas VIII J SMP Negeri 5 Singaraja Tahun Pelajaran 2013/2014 berjumlah 29 siswa yang terdiri atas 14 siswa laki-laki dan 15 siswa perempuan. Sedangkan objek dalam penelitian ini adalah hasil belajar siswa pada mata pelajaran IPS Terpadu dan respon siswa terhadap penggunaan media pembelajaran interaktif berbasis Teknologi, Informasi, dan Komunikasi (TIK).

Penelitian tindakan kelas ini terdiri dari dua siklus. Kemmis dan Mc. Taggart (dalam Arikunto, dkk 2011: 16) menyatakan bahwa dalam setiap siklus memiliki tahapan-tahapan yang meliputi, perencanaan, pelaksanaan tindakan, pengamatan dan evaluasi serta refleksi. Sehingga jika penelitian tindakan kelas ini dirancang dalam dua siklus, maka secara langsung siklus selanjutnya merupakan perbaikan berdasarkan hasil refleksi siklus sebelumnya.

Menurut Arikunto (2003:136) "instrumen penelitian adalah suatu alat atau fasilitas yang digunakan oleh peneliti dalam mengumpulkan data agar lebih mudah dan hasilnya lebih baik dalam arti lebih cermat, lengkap, dan sistematis sehingga lebih mudah diolah". Instrumen yang digunakan dalam penelitian ini adalah sebagai berikut.

(1) Tes Hasil Belajar

Tes hasil belajar menggunakan soal untuk mengukur hasil belajar siswa. Adapun bentuk tes ini adalah berupa lembar soal pilihan ganda atau soal obyektif yang sudah divalidasi oleh dua orang ahli (Expert Judgement) yaitu 
guru mata pelajaran IPS Drs. I Made Santika dan Indal, S.Pd. Skor untuk masing-masing ítem tes obyektif tergambar dalam Tabel 1.

Tabel 1. Rubrik Penilaian Item Tes Obyektif

\begin{tabular}{lc}
\hline Kriteria & Skor \\
\hline Menjawab benar. & 1 \\
Salah/tidak menjawab & 0 \\
\hline
\end{tabular}

(2) Angket

Angket digunakan untuk mengukur respon siswa terhadap penggunaan media pembelajaran interaktif berbasis TIK. Angket respon siswa kemudian akan divalidasi dengan menggunakan validitas isi yang merupakan validitas dengan didasarkan pada pertimbangan para ahli terhadap ketepatan suatu instrumen di dalam mengukur perubahan-perubahan psikologis yang timbul pada diri siswa setelah mengalami proses pembelajaran tertentu. Angket yang digunakan yaitu model skala Likert dengan pilihan sangat setuju (SS), setuju (S), ragu-ragu (R), tidak setuju (TS), dan sangat tidak setuju (STS). Adapaun kriteria pemberian skor jawaban respon siswa dapat dilihat pada Tabel 2.

\begin{tabular}{lc} 
Tabel 2. & $\begin{array}{c}\text { Kriteria } \\
\text { Jawaban Respon Siswa }\end{array}$ \\
\hline Jawaban Angket & $\begin{array}{c}\text { Skor Item } \\
\text { Jawaban }\end{array}$ \\
\hline Sangat Setuju (SS) & 5 \\
Setuju (S) & 4 \\
Ragu-ragu (R) & 3 \\
Tidak Setuju (TS) & 2 \\
Sangat Tidak Setuju (STS) & 1 \\
\hline
\end{tabular}

\section{HASIL DAN PEMBAHASAN HASIL}

Berdasarkan rumusan masalah yang sudah dipaparkan pada bab pendahuluan, maka paparan hasil penelitian mengacu pada dua permasalahan yakni, (1) hasil belajar mata pelajaran IPS terpadu siswa dengan penggunaan media pembelajaran interaktif berbasis TIK, dan (2) respons siswa terhadap penggunaan media pembelajaran interaktif berbasis TIK. Pada siklus I materi yang diberikan adalah hubungan kelangkaan sumber daya dengan kebutuhan manusia. Sedangkan pertemuan pada siklus II, materi yang diberikan adalah pelaku ekonomi. Tiap siklus dirinci menjadi empat kali pertemuan yang dibagi menjadi tiga kali pertemuan unjuk kerja dan satu kali pertemuan tes akhir siklus. Setiap pertemuan dilaksanakan dua kali dalam seminggu yaitu hari Selasa dan Rabo dengan alokasi waktu 2 jam pelajaran (2 X 45 menit) setiap pertemuan. Peneliti dalam hal ini berperan sebagai guru yang menggunakan media pembelajaran interaktif berbasis TIK dalam proses pembelajaran di kelas VIII J SMP Negeri 5 Singaraja.

Hasil belajar IPS terpadu siswa dengan penggunaan media pembelajaran interaktif berbasis TIK pada pokok bahasan hubungan kelangkaan sumber daya dengan kebutuhan manusia dilihat pada hasil belajar individu siswa. Hasil belajar dengan tes dilakukan setiap akhir siklus. Sebaran hasil belajar siswa pada siklus I seperti tampak pada Tabel 3

Berdasarkan analisis data pada Tabel 3 diperoleh nilai rata-rata hasil belajar siswa secara keseluruhan adalah sebesar 69,87, sehingga jika dibandingkan dengan pedoman konversi hasil belajar, maka diperoleh jumlah siswa yang berada pada kategori sangat kurang baik sebanyak 5 orang siswa $(17,24 \%)$, kategori kurang baik sebanyak 4 orang siswa (13,79\%), kategori cukup baik sebanyak 14 orang siswa $(48,28 \%)$, kategori baik sebanyak 5 orang siswa $(17,24 \%)$ dan kategori baik sekali sebanyak 1 orang siswa (3,45\%). 
Tabel 3. Sebaran Hasil Belajar Siswa Pada Masing-Masing Kategori Untuk Siklus I

\begin{tabular}{cccc}
\hline Rentangan & Kategori & Jumlah siswa & Persentase \\
\hline $0-54$ & Sangat kurang baik & 5 & $17,24 \%$ \\
$55-64$ & Kurang baik & 4 & $13,79 \%$ \\
$65-79$ & Cukup baik & 14 & $48,28 \%$ \\
$80-89$ & Baik & 5 & $17,24 \%$ \\
$90-100$ & Baik Sekali & 1 & $3,45 \%$ \\
Jumlah & & 29 & $100,00 \%$ \\
\hline
\end{tabular}

Berdasarkan hasil belajar siswa pada siklus I dan dari standar KKM pada mata pelajaran IPS yang ditentukan oleh SMP Negeri 5 Singaraja yaitu 72 maka dapat diketahui jumlah siswa yang tuntas dan yang belum tuntas dalam pembelajaran IPS terpadu untuk siklus I dapat dilihat dalam Tabel 4.

Tabel 4. Jumlah Siswa yang Tuntas dan Tidak Tuntas

\begin{tabular}{lcc}
\hline Keterangan & $\begin{array}{c}\text { Jumlah } \\
\text { siswa }\end{array}$ & Persentase \\
\hline Tuntas & 19 & $65,52 \%$ \\
Belum tuntas & 10 & $34,48 \%$ \\
Jumlah & 29 & $100 \%$ \\
\hline
\end{tabular}

\section{Berdasarkan pelaksanaan} tindakan pada siklus I, terungkap beberapa kendala atau hambatan yang perlu dicermati dalam penggunaan media pembelajaran interaktif berbasis TIK di kelas VIII J SMP Negeri 5 Singaraja. Adapun beberapa kendala atau hambatan dalam penggunaan media pembelajaran interaktif berbasis TIK adalah sebagai berikut.

(1) Proses pelaksanaan pembelajaran pada siklus pertama masih belum berjalan secara optimal. Hal ini disebabkan karena siswa belum sepenuhnya mampu mengikuti dan beradaptasi dalam penggunaan media pembelajaran interaktif berbasis TIK yang digunakan guru.

(2) Dalam proses pembelajaran yang dilakukan, siswa masih terbiasa dengan pola pembelajaran sebelumnya, karena pada pola sebelumnya siswa hanya menerima informasi langsung dari guru sehingga siswa kurang aktif dalam bertanya.
(3) Hasil belajar siswa tidak mengalami peningkatan secara signifikan karena rata-rata nilai siswa secara keseluruhan masih dalam kategori cukup baik. Hal ini disebabkan karena penggunaan media pembelajaran interaktif berbasis TIK yang dilakukan oleh peneliti dalam pembelajaran IPS Terpadu belum sepenuhnya dapat diikuti siswa dalam proses pembelajaran, karena siswa secara tidak sadar masih bersifat konvensional yang beranggapan bahwa hanya guru yang bertanggungjawab untuk menyampaikan materi. Sehingga siswa masih belum terfokus dan terlibat sepenuhnya dalam proses pembelajaran yang dilakukan oleh peneliti.

Dengan mencermati kendalakendala dan permasalahan di atas, maka untuk mendapatkan hasil yang optimal, peneliti merumuskan dan melakukan beberapa upaya untuk perbaikan pada siklus II sebagai berikut.

(1) Sebelum melaksanakan tindakan pada siklus II, siswa diberikan arahan kembali mengenai proses pembelajaran yang menggunakan media interaktif berbasis TIK dan guru hanya sebagai fasilitator dan mediator. Siswa diberikan kesempatan untuk meningkatkan kualitas belajarnya melalui penggunaan media pembelajaran interaktif berbasis TIK yang diterapkan peneliti.

(2) Siswa diingatkan bahwa setiap penilaian yang dilakukan oleh peneliti akan dimasukkan ke dalam nilai raport. Hal tersebut dilakukan dengan harapan siswa dapat belajar secara optimal dan memahami pelaksanaan proses 
pembelajaran sehingga hasil belajar siswa lebih maksimal.

(3) Menghimbau kepada siswa pada akhir pertemuan/tindakan agar menyiapkan materi dari rumah sehingga proses pembelajaran selanjutnya dilaksanakan secara optimal dan lancar.

(4) Memberikan pemahaman awal tentang konsep materi yang dibahas sebelum memulai pembelajaran dengan harapan siswa dapat menjadikan pegangan pemahamannya dalam proses pelaksanaan pembelajaran.

Kurang maksimalnya penggunaan media pembelajaran interaktif berbasis TIK dalam proses pembelajaran mesti dilakukan langkah perbaikan dengan menyusun media pembelajaran interaktif berbasis TIK yang menarik, sederhana, singkat, padat dan mudah dipahami oleh siswa serta bisa memberikan dorongan kemauan siswa untuk berinteraksi dan aktif dalam pembelajaran di dalam kelas.

Hasil belajar IPS terpadu siswa dengan penggunaan media pembelajaran interaktif berbasis TIK pada pokok bahasan pelaku ekonomi bisa dilihat pada hasil belajar individu siswa. Hasil belajar dengan tes dilakukan setiap akhir siklus. Sebaran hasil belajar siswa pada siklus II seperti tampak pada Tabel 5.

Tabel 5. Sebaran Hasil Belajar Siswa Pada Masing-Masing Kategori Untuk Siklus II

\begin{tabular}{cccc}
\hline Rentangan & Kategori & Jumlah siswa & Persentase \\
\hline $0-54$ & Sangat kurang baik & 0 & $0,00 \%$ \\
$55-64$ & Kurang baik & 0 & $0,00 \%$ \\
$65-79$ & Cukup baik & 11 & $37,93 \%$ \\
$80-89$ & Baik & 13 & $44,83 \%$ \\
$90-100$ & Baik Sekali & 5 & $17,24 \%$ \\
Jumlah & & 29 & $100 \%$ \\
\hline
\end{tabular}

Berdasarkan analisis data pada Tabel 4.3 diperoleh jumlah siswa yang berada pada kategori sangat kurang baik sebanyak 0 orang siswa $(0,00 \%)$, kategori kurang baik sebanyak 0 orang siswa $(0,00 \%)$, kategori cukup baik sebanyak 11 orang siswa (37,93\%), kategori baik sebanyak 13 orang siswa $(44,83 \%)$ dan kategori baik sekali sebanyak 5 orang siswa $(17,24 \%)$ dengan rata-rata nilai hasil belajar siswa secara keseluruhan adalah 80,0.

Berdasarkan hasil belajar siswa dan dari standar KKM pada mata pelajaran IPS yang ditentukan oleh SMP Negeri 5 Singaraja yaitu 72 maka dapat diketahui jumlah siswa yang tuntas dan yang belum tuntas dalam pembelajaran IPS terpadu dengan penggunaan media pembelajaran interaktif berbasis TIK untuk siklus II dapat dilihat dalam Tabel 6.
Tabel 6. Jumlah Siswa yang Tuntas dan Belum Tuntas Pada Siklus II

\begin{tabular}{lcc}
\hline Keterangan & $\begin{array}{c}\text { Jumlah } \\
\text { siswa }\end{array}$ & Persentase \\
\hline Tuntas & 27 & $93,10 \%$ \\
Belum tuntas & 2 & $6,90 \%$ \\
Jumlah & 29 & $100 \%$ \\
\hline
\end{tabular}

Adapun hasil pelaksanaan pembelajaran dengan menggunakan media pembelajaran interaktif berbasis TIK adalah sebagai berikut.

(1) Penggunaan media pembelajaran interaktif berbasis TIK pada proses pembelajaran IPS Terpadu kelas VIII J mengalami peningkatan hasil belajar siswa. Hal ini disebabkan karena siswa sudah mampu berinteraksi dengan media pembelajaran interaktif berbasis TIK, sehingga siswa lebih terbantu dalam proses pembelajaran dilakukan.

(2) Secara umum penggunaan media pembelajaran interaktif berbasis 
TIK telah berjalan sesuai dengan hasil refleksi siklus I. Kondisi proses pembelajaran pada siklus II tampak lebih kondusif dan optimal, terbukti dari adanya peningkatan keinginan belajar siswa yang tinggi setelah adanya perbaikan terhadap kekurangan pembelajaran pada siklus I.

(3) Hasil pembelajaran siswa meningkat pada siklus II dibuktikan dengan adanya peningkatan jumlah siswa yang tuntas.

(4) Rata-rata hasil belajar siswa secara keseluruhan mengalami peningkatan, yaitu dari kategori cukup baik menjadi kategori baik.

(5) Respon siswa terhadap penggunaan media pembelajaran interaktif berbasis TIK sangat tinggi, terbukti dari keaktifan siswa dalam bertanya di dalam kelas.

Hasil refleksi pada siklus II ini dipakai sebagai rekomendasi bagi guru mata pelajaran IPS Terpadu yang ingin menggunakan media pembelajaran interaktif berbasis TIK.

Data respon siswa terhadap penerapan media pembelajaran interaktif berbasis TIK dari angket yang diberikan pada akhir siklus II, jumlah skor respon siswa pada siklus kedua diperoleh sebesar 1210. Sehingga ratarata respon siswa adalah 41,79. Respon siswa terhadap penggunaan media pembelajaran interaktif berbasis TIK seperti tampak pada Tabel 7 .

Tabel 7. Sebaran Respon Siswa Terhadap Penggunaan Media Pembelajaran Pembelajaran Interaktif Berbasis TIK

\begin{tabular}{cccc}
\hline Kriteria & Jumlah Siswa & Persentase & Kategori \\
\hline$\overline{\boldsymbol{x}} \geq 45$ & 6 & $20,69 \%$ & Sangat Positif \\
$35 \leq \overline{\boldsymbol{x}}<45$ & 15 & $51,72 \%$ & Positif \\
$25 \leq \overline{\boldsymbol{x}}<35$ & 8 & $27,59 \%$ & Cukup Positif \\
$15 \leq \overline{\boldsymbol{x}}<25$ & 0 & 0 & Kurang Positif \\
$\overline{\boldsymbol{x}}<15$ & 0 & 0 & Sangat Kurang Positif \\
\hline
\end{tabular}

Dari data tersebut diketahui bahwa pada siklus II, siswa yang memberikan respons sangat positif sebanyak 6 orang siswa $(20,69 \%)$, yang memberikan respon positif sebanyak 15 orang siswa $(51,72 \%)$, yang memberikan respon cukup positif sebanyak 8 orang siswa $(27,59 \%)$, serta tidak ada siswa yang memberikan respon kurang positif dan sangat kurang positif terhadap penggunaan media pembelajaran interaktif berbasis TIK. Untuk skor rata-rata respon siswa secara keseluruhan sebesar 41,72 dengan kategori positif.

\section{PEMBAHASAN}

Berdasarkan hasil penelitian yang telah dilaksanakan selama dua siklus, penelitian ini menunjukkan terjadinya peningkatan hasil belajar siswa dengan penggunaan media pembelajaran interaktif berbasis TIK.
Hasil analisis nilai hasil belajar siswa pada siklus I menunjukkan bahwa pada siklus pertama hasil belajar siswa kurang maksimal dengan perolehan rata-rata hasil belajar siswa sejumlah 69,87. Pada siklus I dari jumlah siswa sebanyak 29 orang, diperoleh jumlah yang tuntas adalah 19 orang (65,52\%) sedangkan yang belum tuntas sebanyak 10 orang siswa (34,48\%). Belum tercapainya keberhasilan proses pembelajaran disebabkan oleh beberapa temuan kendala-kendala dan permasalahan yang terjadi selama pelaksanaan siklus I seperti yang telah dipaparkan pada hasil refleksi siklus I.

Berdasarkan refleksi siklus । diadakan perbaikan proses pembelajaran sehingga pada pelaksanaan siklus II diperoleh adanya peningkatan nilai rata-rata hasil belajar siswa secara keseluruhan. Rata-rata hasil belajar siswa secara keseluruhan pada siklus II sebesar 80. Pada siklus II 
jumlah siswa yang tuntas mengalami peningktan dari siklus sebelumnya sebesar 27 orang siswa $(93,10 \%)$, dan yang belum tuntas sebesar 2 orang siswa $(6,90 \%)$.

Pada pelaksanaan tindakan siklus I dan II, jika dibandingkan tampak terlihat terjadi peningkatan hasil belajar siswa yang dibuktikan dengan hasil belajar rata-rata siswa secara keseluruhan pada siklus I adalah 69,87, sedangkan rata-rata hasil belajar siswa secara keseluruhan pada siklus II adalah sebesar 80,00. Hal ini menunjukkan bahwa penggunaan media pembelajaran interaktif berbasis TIK dapat meningkatkan hasil belajar siswa dalam pembelajaran IPS Terpadu.

Penelitian tindakan kelas dengan penggunaan media pada mata pelajaran IPS Terpadu di SMP Negeri 5 Singaraja kelas VIII J sangat menarik perhatian tanggapan siswa sesuai dengan analisis respons siswa. Setelah disebarkan kuesioner respon siswa kepada siswa maka diperoleh nilai rata-rata respon siswa adalah 41,72. Jika dibandingkan dengan skala konvensi maka kategori respon siswa berada pada kategori positif. Dari jumlah siswa yang ada yaitu 29 orang siswa diperoleh 6 orang siswa $(20,69 \%)$ berada pada kategori sangat positif, 15 orang siswa $(51,72 \%)$ berada pada kategori positif, dan 8 orang siswa $(27,59)$ berada pada kategori cukup positif.

Dari hasil analisis data yang dilakukan maka penggunaan media pembelajaran interaktif berbasis TIK pada mata pelajaran IPS Terpadu memberikan suatu indikasi keberhasilan dalam upaya meningkatkan hasil belajar siswa. Peningkatan hasil belajar siswa dengan penggunaan media pembelajaran interaktif berbasis TIK sejalan dengan pendapat Wena (2009: 204) yang menyatakan bahwa: "Melalui penggunaan media pembelajaran interaktif berbasis TIK dalam proses pembelajaran akan mampu melukiskan konsep/prinsip dalam suatu pembelajaran yang bersifat abstrak dan kompleks menjadi suatu yang nyata, sederhana, sitematis dan sejelas mungkin. Dengan demikian penggunaan media pembelajaran interaktif berbasis TIK dalam proses pembelajaran akan membuat kegiatan pembelajaran berlangsung secara tepat guna dan berdaya guna sehingga dapat meningkatkan hasil belajar siswa". Jadi keuntungan utama penggunaan media pembelajaran interaktif berbasis TIK yang dilakukan oleh guru adalah dapat meningkatkan hasil belajar siswa. Dengan demikian dapat disimpulkan bahwa penggunaan media pembelajaran interaktif berbasis TIK dapat mempermudah guru dalam penyampaian materi di dalam kelas dan memberikan gambaran secara luas materi yang disampaikan guru serta berimplikasi terhadap hasil belajar siswa.

Lebih lanjut berdasarkan refleksi hasil penelitian bahwa penggunaan media pembelajaran interaktif berbasis TIK pada mata pelajaran IPS Terpadu memiliki beberapa kebaikan yang dapat dimanfaatkan dan penelitian ini juga bisa digunakan sebagai bahan rekomendasi bagi guru dalam pembelajaran di dalam kelas. Adapun kebaikan-kebaikan tersebut adalah sebagai berikut.

(1) Penggunaan media pembelajaran interaktif berbasis TIK pada mata pelajaran IPS Terpadu dapat merangsang keinginan siswa untuk belajar.

(2) Guru bebas memberikan penyampaian materi kepada siswa karena dengan penggunaan media pembelajaran interaktif berbasis TIK guru lebih leluasa memberikan contoh nyata kepada siswa, karena media pembelajaran interaktif berbasis TIK bisa menampilkan contoh yang tidak mungkin dibawa ke dalam kelas.

(3) Penggunaan media pembelajaran interaktif berbasis TIK mendorong siswa untuk meningkatkan keingintauan siswa terhadap materi 
yang diajarkan, sehingga siswa akan terangsang untuk bertanya.

Dengan penggunaan media pembelajaran interaktif berbasis TIK antara siswa dan guru ada interaksi yang bagus, karena dengan penggunaan media pembelajaran interaktif berbasis TIK guru tidak hanya sekedar memberikan informasi tapi juga bisa membantu kesulitan beajar siswa. Sehingga guru dengan siswa berinteraksi secara langsung.

\section{SIMPULAN DAN SARAN SIMPULAN}

Berdasarkan

hasil dan pembahasan yang telah dilakukan, dapat disimpulkan hal-hal sebagai berikut.

(1) Penggunaan media pembelajaran interaktif berbasis Teknologi, Informasi, dan Komunikasi (TIK) dapat meningkatkan hasil belajar IPS Terpadu pada siswa kelas VIII J SMP Negeri 5 Singaraja. Hal ini dapat dilihat pada siklus I hasil belajar siswa mencapai ketuntasan $65,52 \%$ dengan nilai rata-rata 69,87 . Pada siklus II mengalami peningkatan dengan ketuntasan belajar $93,10 \%$ dengan nilai ratarata siswa secara keseluruhan adalah 80,00.

(2) Dengan penggunaan media pembelajaran interaktif berbasis TIK pada kelas VIII J SMP Negeri 5 Singaraja memberikan respons positif dengan nilai rata-rata respons siswa sebesar 41,79 . Hal ini berarti penggunaan media pembelajaran interaktif berbasis TIK sudah berhasil diikuti dengan baik oleh siswa

\section{SARAN}

Berdasarkan simpulan penelitian di atas, dapat dikemukakan beberapa saran sebagai berikut.

(1) Berdasarkan hasil refleksi masingmasing siklus, evaluasi dan temuantemuan yang diperoleh selama melakukan penelitian, diharapkan penggunaan media pembelajaran interaktif berbasis TIK dapat menjadi alternatif dalam memecahkan masalah proses pembelajaran IPS Terpadu di sekolah sehingga dapat meningkatkan hasil belajar siswa.

(2) Diharapkan kepada guru IPS Terpadu untuk menggunakan media pembelajaran interaktif berbasis TIK dalam setiap kegiatan proses pembelajaran, sehingga tujuan pembelajaran yang diharapkan dapat tercapai.

\section{DAFTAR PUSTAKA}

Arikunto, Suharsimi. 2003. Prosedur Penelitian, Suatu Praktek, Jakarta: Bina Aksara.

Arikunto, Suharsimi, dkk. 2011. Peneitian Tindakan Kelas Cet. IV, Jakarta: Bumi Aksara.

Arsyad, Azhar. 2002. Media Pengajaran, Jakarta: Raja Grafindo Persada.

------, 2009. Media Pembelajaran, Jakarta: Raja Grafindo.

Djamarah, Syaiful, Bahri. 2003. Strategi Belajar Mengajar, Jakarta: PT. Rineka Cipta.

Krisnadi, Elang. 2009. Rancangan Materi Pembelajaran Berbasis TIK, disajikan dalam Workshop Pengembangan Materi Pembelajaran Berbasis TIK di FMIPA UNY pada tanggal 6 Agustus 2009.

Sabri, Ahmad, 2005. Strategi Belajar Mengajar Dan Micro Teaching, Jakarta: Quantum Teaching.

Slameto. 2003. Belajar dan FaktorFaktor Yang Mempengaruhi Belajar, Jakarta: Rhineka Cipta.

Sudjana, Nana, 2004. Dasar-dasar Proses Belajar Mengajar,Bandung: PT. Sinar Baru Algesindo. 
2004. Penilaian Hasil Proses Belajar Mengajar, Bandung: PT Remaja Rosdakarya Offset.

-------, 2005. Penilaian Hasil Proses Belajar Mengajar, Bandung: PT Remaja Rosdakarya Offset.
Usman, M. Basyiruddin dan Asnawir. 2002. Media Pembelajaran. Jakarta: Delia Citra Utama.

Wena, Made. 2009. Strategi Pembelajaran Inovatif Kontemporer: Suatu Tinjauan Konseptual Operasional. Jakarta: Bumi Aksara. 